\title{
Assessment of biomarker with special reference to antioxidant level in blood as occupational exposure of sewage and garage workers
}

\author{
Rajlaxmi Basu1, Soumendra Nath Talapatra ${ }^{2}$, Aniruddha Mukhopadhyay ${ }^{2}$, \\ Siddhartha Shankar Ray ${ }^{1}$, Prantar Chakrabarti ${ }^{1}$, Utpal Chaudhuri ${ }^{1}$, \\ Sila Chakrabarti ${ }^{1, *}$ \\ ${ }^{1}$ Institute of Hematology and Transfusion Medicine, Medical College, Kolkata -700073, India \\ ${ }^{2}$ Department of Environmental Science, University of Calcutta, Kolkata -700019, India \\ *E-mail address: shilachakrabarti2@gmail.com
}

\begin{abstract}
The present study deals with the estimation of antioxidant levels in blood of sewage and garage workers exposed to sewage water, washing water and vehicular air pollution compared with control group of population. The study areas were selected on the basis of drainage clearance and wards where workers are active as sewage workers. For garage workers, the garage selected was a large and busy one where continuous vehicles washing, repairing etc are carried out. These two exposed groups were compared to non-exposed group of population as control. The blood samples were collected from two groups of exposed population as well as control population and the antioxidant levels were estimated in blood. The present results clearly indicate that there was decreasing trend of the antioxidant level in blood for sewage and garage workers. In the control groups of population the antioxidant levels were found to be within normal range, but for sewage workers $(0.14-0.36 \mathrm{mM})$ and garage workers $(0.12-0.36 \mathrm{mM})$ the antioxidant levels were significantly lower. The range of antioxidant level in human blood is 0.5 to $2.0 \mathrm{mM}$. It was found to be significantly lower $(\mathrm{P}<0.001$ or 0.05 ) in addicted sewage and garage workers when compared with non-addicted groups. All the exposed groups were showed to be having significantly lower antioxidant level when compared to control groups. This study is a preliminary assessment to know the potent biomarkers for oxidative stress and estimation of antioxidant level in blood due to occupational exposure. This study shows a way for easy screening of biomarker assessment but further work is needed in relation to biochemical, enzymological and genetic damage study.
\end{abstract}

Keywords: Waste water; Occupational exposure; Human blood; Antioxidant level

\section{INTRODUCTION}

Sewage water in municipality drains has already been reported as genotoxic and mixed with small scale industrial effluent (Hough, 1997). Previous workers (Tiwari 2008) has already been documented that sewage water causes occupational health hazards in sewage and sanitary workers. Apart from organic pollutants sewage water is contaminated by different metals especially lead $(\mathrm{Pb})$ and cadmium $(\mathrm{Cd})$. In urban area, large number of local 
automobile repair shops, has led to increased $\mathrm{Pb}$ contamination in sewage water (Hertwin, 2013). Air pollutants mainly hydrocarbons, aromatic hydrocarbons, particulate matters etc. are generated in the automobile repairing shop (garage). These pollutants are also present in automobile waste water which is randomly handled by automobile workers. Epidemiological studies have demonstrated that increased levels of airborne particles are associated with adverse health effects, such as cancer, cardiovascular and pulmonary diseases (Brook et al., 2010). Health impact of water and air pollution depends on the pollutant type, its concentration in the water and air, length of exposure, other pollutants in the water and air, and individual susceptibility. Poor people, undernourished people, very young and very old, and people with pre-existing respiratory disease and other ill health are more at risk (VichitVadakan et al., 2010).

The multiple defense system present in our body against damaging free radicals is collectively called as antioxidants and these can be easily measuared (Gupta et al., 2009).). Among the different mechanisms proposed to explain these adverse effects, the production of reactive oxygen species (ROS) and the generation of oxidative stress is a matter of great concern. ROS include both oxygenated radicals and certain closed shell species that are oxidizing agents. Under normal coupling conditions in the mitochondrion, ROS are generated at low frequency and are easily neutralized by antioxidant defenses. However, in the presence of oxidants, such as following exposure to particles, heavy metals the natural antioxidant defenses may be.

Many studies have already been reported on oxidative stress by occupational exposure and increase of ROS level in blood (Penning et al., 1999; Gaetke and Chow, 2003; Riediker et al., 2004; Bergamini et al., 2009; Cuypers et al., 2010; Hertwin, 2013). The estimation of antioxidant level is a potent biomarker assessment in human model (Gupta et al., 2009).A number of studies have already been carried out on health impacts overwhelmed (Halliwell and Gutteridge, 2007; Cuypers et al., 2010) by sewage water, washing water from vehicles and vehicular air pollution as different pollutants individually and/or in combination but no one has attempted easy screening of biomarker with special reference to estimate antioxidant level in blood of sewage and garage workers to know water and air pollutants exposure to human.

Though a number of studies have been carried out on effects of sewage water and garage effluents on human health, to the best of our knowledge this is the first effort to correlate the level of total antioxidants in blood of professionally exposed workers and thus determine their exposure status and potentially harmful effects on health in India.

\section{MATERIALS AND METHODS}

\section{Study area}

The selected study area was southern part of Kolkata (India). The areas selected were ones, where drainage clearance and other conservancy work is good and ward workers are active too as sewage workers. For garage workers, the garage was selected where continuous vehicles washing, repairing are taken care of. These two areas were compared to nonexposed group of population.

\section{Questionnaires and blood Collection}

Following questionnaires was used for sewage workers, garage workers and nonexposed population as control group before collection of blood sample. 


\section{Questionnaires}

1. Name

2. Age

3. Sex

4. Living area

5. Exact mode of work

6. Working duration /day

7. No. of years working

8. Medicinal history/Habit

9. Food habit

10. Family disease history

11. Addiction history and present status

12. Time of food inking

13. Working safety measure if maintain or not

\section{Blood sample collection}

The subjects to be eligible for the study must be Indian adult and should be been living for a long stretch of time (at least 5 years) in south Kolkata region and working strictly on drainage and garage work. Exposed (drainage and garage workers of Kolkata) and control population (living in the same area but never being exposed to such polluted and toxic water) were asked to answer questions in order to verify any possible additional exposure through ingestion of food, smoking, use of medicine, and any other relevant information. The information was particularly useful in the evaluations of final data.

The exposed male and female workers were selected for the experiment that were engaged in drainage and garage work (only male workers) but randomly handle sewage water and washing water every day and also take their food without proper hand washing especially during working hour. After Ethical committee clearance $5 \mathrm{ml}$ of blood was drawn from each subject under proper medical supervision and care.

The blood obtained were kept in a citrate $(3.8 \%)$ container and stored in $4{ }^{\circ} \mathrm{C}$ refrigerators for further experiment. Similarly venous blood $(5 \mathrm{ml})$ was taken from healthy male as control group of population.

\section{Estimation of antioxidant from blood samples}

Antioxidant assay was used to measure the total antioxidant capacity of Plasma. Aqueous and lipid soluble antioxidants are not separated in this protocol, thus the combined antioxidant activities of all its constituents including vitamins, proteins, lipids, glutathione, 
uric acid, etc are assessed. This assay relies on the ability of antioxidants in the sample to inhibit the oxidation of ABTS (2,2,-azino-di-[3-ethylbenzthiazoline sulphonate]) to ABTS ${ }^{\bullet+}$ by metmyoglobin. The amount of $\mathrm{ABTS}^{\bullet+}$ produced can be monitored by reading the absorbance at $405 \mathrm{~nm}(13,14)$ the capacity of the antioxidant in the sample to prevent ABTS oxidation is compared with that of Trolox, a water soluble tocopherol analogue, and is quantified as milimolar Trolox equivalaents. The collected blood was centrifuged at $1000 \mathrm{~g}$ for 8 minutes at $4{ }^{\circ} \mathrm{C}$. The yellow supernatant was pipette out without disturbing the white Buffy layer. This plasma was stored at $-80^{\circ} \mathrm{C}$ for further assay. Plasma was diluted 1:30 with assay buffer $(5 \mathrm{mM}$ potassium phosphate, $\mathrm{pH} 7.4$, containing $0.9 \%$ sodium chloride and 0.1 $\%$ glucose) before assaying for garage workers. But it case of sewage and obviously for control group further dilution was applied because it was expected that these population may rich in antioxidant capacity. In sample well $10 \mu \mathrm{L}$ of sample, $10 \mu \mathrm{L}$ of Metmyoglobin and $150 \mu \mathrm{L}$ of Chromogen was added. Reaction was initiated by adding $40 \mu$ LHydrogen peroxide (441 $\mu \mathrm{M}$ working solution) and the absorbance was estimated in spectrophotometer.

\section{Statistical analysis}

All the mean values of data were analyzed to determine statistically significant differences between exposed and control groups as well as between garage and sewage exposed populations by using Student's t-test at 0.05 levels.

\section{RESULTS}

The range of antioxidant level in human blood is 0.5 to $2.0 \mathrm{mM}$. The present results clearly indicate that there was decreasing trend of the antioxidant level in blood for sewage and garage workers but in the control groups of population found within the range but in individual data there was found much lower the standard range for sewage workers $(0.14-$ $0.36 \mathrm{mM})$ and garage workers $(0.12-0.36 \mathrm{mM})$ those who are addicted but in both the occupations, workers without addiction were also found decline level (Table 1, $2 \& 3$ ). It was found significant changes $(\mathrm{P}<0.001,0.01$ or 0.05$)$ in addicted sewage and garage workers when compared with non-addicted groups. All the exposed groups were showed significantly declining the antioxidant level when compared to control groups (Table 4).

It was observed in Table 4, the level of antioxidant in blood decreased significantly ( $\mathrm{P}$ $<0.001)$ with a value of $0.26 \pm 0.09 \mathrm{mM}$ in garage workers followed by sewage workers $(0.35$ $\pm 0.11 \mathrm{mM})$ as occupational exposure along with addiction when compared with control groups $(0.77 \pm 0.04 \mathrm{mM})$. All the data were generated separately for male, female and cumulative groups. But in case of addicted group, addicted females were not found in control population and no females were worked as garage workers. for both addicted and nonaddicted groups of population while in non-addicted groups of population there was the value of antioxidant level in blood also decreased significantly $(\mathrm{P}<0.001)$ in garage workers $(0.39$ $\pm 0.06 \mathrm{mM})$ followed by sewage workers $(0.49 \pm 0.10 \mathrm{mM})$ when compared with control groups $(1.07 \pm 0.25 \mathrm{mM})$ as same in manner like male, female and cumulative groups.

The comparison between male, female and cumulative groups the values were not found statistically significant. When the comparison made between sewage $(0.35 \pm 0.11$ and $0.49 \pm 0.10 \mathrm{mM})$ and garage workers $(0.26 \pm 0.09$ and $0.39 \pm 0.06 \mathrm{mM})$, the cumulative values were found statistically significant $(\mathrm{P}<0.05)$ for both addicted groups as well as non addicted groups. 
Table 1. Antioxidant level in human blood exposed to sewage water from sewage.

\begin{tabular}{|c|c|c|c|c|c|c|c|}
\hline Sl. No. & Sex & Age & $\begin{array}{l}\text { Working } \\
\text { years }\end{array}$ & $\begin{array}{c}\text { Vegetables } \\
\text { and fruits } \\
\text { intake }\end{array}$ & $\begin{array}{c}\text { Animal proteins } \\
\text { intake }\end{array}$ & Addiction & $\begin{array}{l}\text { Antioxidant } \\
\text { level }(\mathbf{m M})\end{array}$ \\
\hline 1 & Female & 50 & 40 & Regularly & Casually & Tobacco & 0.3 \\
\hline 2 & Female & 50 & 40 & Casually & Regularly & Tobacco & 0.3 \\
\hline 3 & Female & 32 & 8 & no & Regularly & None & 0.35 \\
\hline 4 & Female & 40 & 20 & Regularly & Casually & None & 0.44 \\
\hline 5 & Female & 35 & 2 & Casually & Regularly & Tobacco & 0.42 \\
\hline 6 & Female & 55 & 20 & Regularly & None & $\begin{array}{c}\text { Occasionally } \\
\text { Tobacco }\end{array}$ & 0.42 \\
\hline 7 & Female & 45 & 27 & Sometimes & Sometimes & None & 0.63 \\
\hline 8 & Female & 35 & 8 & Casually & Regularly & None & 0.5 \\
\hline 9 & Female & 45 & 25 & Rarely & Regularly & None & 0.52 \\
\hline 10 & Female & 35 & 10 & Rarely & Regularly & None & 0.55 \\
\hline 11 & Female & 35 & 1 & Rarely & Regularly & None & 0.47 \\
\hline 12 & Female & 24 & 1 & Rarely & Regularly & Tobacco & 0.45 \\
\hline 13 & Female & 50 & 20 & Casually & Regularly & Tobacco & 0.48 \\
\hline 14 & Female & 35 & 10 & Casually & Regularly & None & 0.51 \\
\hline 15 & Male & 49 & 27 & Casually & Regularly & Alcohol, Tobacco & 0.14 \\
\hline 16 & Male & 50 & 20 & Casually & Regularly & Alcohol, Tobacco & 0.15 \\
\hline 17 & Male & 47 & 18 & Regularly & Regularly & Alcohol, Tobacco & 0.26 \\
\hline 18 & Male & 47 & 20 & Regularly & Regularly & Alcohol, Tobacco & 0.25 \\
\hline 19 & Male & 44 & 23 & Casually & Regularly & Alcohol, Tobacco & 0.21 \\
\hline 20 & Male & 53 & 33 & Regularly & None & None & 0.61 \\
\hline 21 & Male & 34 & 1 & Regularly & Regularly & None & 0.63 \\
\hline 22 & Male & 54 & 28 & Regularly & Regularly & Alcohol, Tobacco & 0.28 \\
\hline 23 & Male & 50 & 32 & Casually & Regularly & Alcohol, Tobacco & 0.21 \\
\hline 24 & Male & 32 & 10 & Rarely & Regularly & Alcohol, Tobacco & 0.32 \\
\hline 25 & Male & 56 & 36 & Regularly & Regularly & Tobacco & 0.33 \\
\hline 26 & Male & 48 & 20 & Casually & Regularly & Alcohol & 0.29 \\
\hline 27 & Male & 50 & 30 & Rarely & Regularly & None & 0.25 \\
\hline 28 & Male & 44 & 11 & Casually & Regularly & Alcohol, tobacco & 0.3 \\
\hline 29 & Male & 39 & 1 & Regularly & None & Alcohol, Tobacco & 0.53 \\
\hline
\end{tabular}




\begin{tabular}{|c|c|c|c|c|c|c|c|}
\hline 30 & Male & 40 & 19 & Casually & Regularly & None & 0.3 \\
\hline 31 & Male & 48 & 28 & Rarely & Regularly & Alcohol, Tobacco & 0.2 \\
\hline 32 & Male & 41 & 12 & Rarely & Regularly & None & 0.33 \\
\hline 33 & Male & 31 & 1 & Rarely & Regularly & None & 0.44 \\
\hline 34 & Male & 40 & 11 & Regularly & Regularly & Alcohol, Tobacco & 0.27 \\
\hline 35 & Male & 26 & 1 & Rarely & Regularly & Alcohol, Tobacco & 0.51 \\
\hline 36 & Male & 45 & 20 & Rarely & Regularly & None & 0.48 \\
\hline 37 & Male & 38 & 18 & Rarely & Regularly & Alcohol & 0.31 \\
\hline 38 & Male & 22 & 4 & Rarely & Regularly & Alcohol, Tobacco & 0.5 \\
\hline 39 & Male & 19 & 1 & Rarely & Regularly & None & 0.49 \\
\hline 40 & Male & 27 & 8 & Regularly & Regularly & Alcohol, Tobacco & 0.55 \\
\hline 41 & Male & 42 & 22 & Regularly & Regularly & Tobacco & 0.45 \\
\hline 42 & Male & 52 & 25 & Casually & Regularly & Alcohol, Tobacco & 0.49 \\
\hline 43 & Male & 46 & 22 & Casually & Regularly & None & 0.57 \\
\hline 44 & Male & 42 & 40 & Rarely & Regularly & None & 0.61 \\
\hline 45 & Male & 35 & 6 & Regularly & Regularly & Tobacco & 0.46 \\
\hline 46 & Male & 23 & 1 & Regularly & Regularly & Tobacco & 0.56 \\
\hline 47 & Male & 50 & 18 & Casually & Regularly & Alcohol, Tobacco & 0.46 \\
\hline 48 & Male & 30 & 11 & Casually & Regularly & Tobacco & 0.57 \\
\hline 49 & Male & 55 & 40 & Rarely & Regularly & Tobacco & 0.21 \\
\hline 50 & Male & 22 & 2 & Regularly & None & None & 0.61 \\
\hline 51 & Male & 42 & 20 & Rarely & Regularly & Alcohol, Tobacco & 0.2 \\
\hline 52 & Male & 40 & 10 & Regularly & None & Alcohol & 0.49 \\
\hline 53 & Male & 42 & 20 & None & Regularly & None & 0.25 \\
\hline 54 & Male & 36 & 16 & None & Regularly & Tobacco & 0.2 \\
\hline 55 & Male & 33 & 6 & Rarely & Regularly & Tobacco & 0.34 \\
\hline 56 & Male & 34 & 8 & Casually & Regularly & Alcohol, Tobacco & 0.25 \\
\hline 57 & Male & 42 & 15 & Regularly & Regularly & None & 0.36 \\
\hline 58 & Male & 52 & 30 & Rarely & Regularly & Alcohol, Tobacco & 0.3 \\
\hline
\end{tabular}


Table 2. Antioxidant level in human blood exposed to washing water and air pollutants from garage.

\begin{tabular}{|c|c|c|c|c|c|c|c|}
\hline $\begin{array}{l}\text { Sl. } \\
\text { No. }\end{array}$ & Sex & Age & $\begin{array}{c}\text { Working } \\
\text { years }\end{array}$ & $\begin{array}{l}\text { Vegetables and } \\
\text { fruits intake }\end{array}$ & $\begin{array}{c}\text { Animal } \\
\text { proteins intake }\end{array}$ & Addiction & $\begin{array}{l}\text { Antioxidant } \\
\text { level (mM) }\end{array}$ \\
\hline 1 & Male & 19 & 2months & Casually & Regularly & None & 0.46 \\
\hline 2 & Male & 39 & 15 & Regularly & Regularly & Tobacco, Alcohol & 0.12 \\
\hline 3 & Male & 29 & 1.5 & Regularly & Regularly & Tobacco & 0.42 \\
\hline 4 & Male & 31 & 5 & Regularly & None & Tobacco, Alcohol & 0.47 \\
\hline 5 & Male & 26 & 3 & Regularly & Regularly & None & 0.4 \\
\hline 6 & Male & 23 & 3 & Regularly & None & Tobacco & 0.42 \\
\hline 7 & Male & 24 & 8 & Regularly & Regularly & None & 0.41 \\
\hline 8 & Male & 34 & 6 & Regularly & Regularly & None & 0.46 \\
\hline 9 & Male & 24 & 7 months & Regularly & Regularly & None & 0.44 \\
\hline 10 & Male & 40 & 25 & Regularly & Regularly & None & 0.29 \\
\hline 11 & Male & 38 & 20 & Regularly & Regularly & None & 0.32 \\
\hline 12 & Male & 30 & 3 & Regularly & Regularly & None & 0.36 \\
\hline 13 & Male & 29 & 9 & Regularly & Regularly & Alcohol, Tobacco & 0.33 \\
\hline 14 & Male & 26 & 4 & Regularly & Regularly & Tobacco & 0.32 \\
\hline 15 & Male & 28 & 2 & None & Regularly & Alcohol, Tobacco & 0.26 \\
\hline 16 & Male & 24 & 2 & Regularly & Regularly & Tobacco & 0.29 \\
\hline 17 & Male & 26 & 6 & Regularly & Regularly & Alcohol, Tobacco & 0.33 \\
\hline 18 & Male & 45 & 18 & Regularly & Regularly & None & 0.37 \\
\hline 19 & Male & 46 & 15 & Casually & Regularly & Alcohol & 0.32 \\
\hline 20 & Male & 18 & 2 & very rare & Regularly & Tobacco & 0.37 \\
\hline 21 & Male & 38 & 14 & Regularly & Regularly & Alcohol, Tobacco & 0.17 \\
\hline 22 & Male & 30 & 9 & Regularly & Regularly & Alcohol, Tobacco & 0.12 \\
\hline 23 & Male & 18 & 5 & rarely & Regularly & Alcohol, Tobacco & 0.25 \\
\hline 24 & Male & 30 & 14 & Regularly & Regularly & None & 0.46 \\
\hline 25 & Male & 20 & 7 months & Rarely & Regularly & None & 0.42 \\
\hline 26 & Male & 20 & 1 & Rarely & Regularly & Alcohol, Tobacco & 0.36 \\
\hline 27 & Male & 30 & 10 & Rarely & Regularly & Alcohol & 0.17 \\
\hline 28 & Male & 26 & 3 & Regularly & Regularly & Alcohol, Tobacco & 0.3 \\
\hline
\end{tabular}


Table 3. Antioxidant level in human blood of control groups.

\begin{tabular}{|c|c|c|c|c|c|c|c|}
\hline Sl. No. & Sex & Age & $\begin{array}{l}\text { Working } \\
\text { types }\end{array}$ & $\begin{array}{l}\text { Vegetables and } \\
\text { fruits intake }\end{array}$ & $\begin{array}{c}\text { Animal proteins } \\
\text { intake }\end{array}$ & Addiction & $\begin{array}{l}\text { Antioxidant } \\
\text { level }(\mathrm{mM})\end{array}$ \\
\hline 1 & Male & 24 & $\begin{array}{c}\text { House } \\
\text { staff }\end{array}$ & Regularly & Regularly & no & 0.96 \\
\hline 2 & Male & 20 & Student & Regularly & Regularly & no & 0.95 \\
\hline 3 & Male & 27 & Doctor & Regularly & Regularly & no & 0.83 \\
\hline 4 & Male & 25 & Student & Regularly & Regularly & Alcohol & 0.79 \\
\hline 5 & Male & 23 & Student & Regularly & Regularly & Alcohol & 0.74 \\
\hline 6 & Male & 32 & Employee & Regularly & Regularly & Alcohol & 0.83 \\
\hline 7 & Male & 19 & Student & Regularly & Regularly & no & 1.6 \\
\hline 8 & Male & 19 & Student & Regularly & Regularly & no & 1.16 \\
\hline 9 & Male & 19 & Student & Regularly & Regularly & no & 1.4 \\
\hline 10 & Male & 20 & Student & Regularly & Regularly & Alcohol & 0.74 \\
\hline 11 & Male & 21 & Student & Regularly & Regularly & Alcohol & 0.74 \\
\hline 12 & Male & 22 & Student & Regularly & Regularly & no & 1.06 \\
\hline 13 & Female & 30 & Researcher & Regularly & Regularly & no & 1.3 \\
\hline 14 & Female & 28 & Student & Regularly & Regularly & no & 1.3 \\
\hline 15 & Female & 30 & Researcher & Regularly & Regularly & no & 1.38 \\
\hline 16 & Female & 28 & Researcher & Regularly & No & no & 1.32 \\
\hline 17 & Female & 30 & Researcher & Regularly & Regularly & no & 1.2 \\
\hline 18 & Female & 30 & Researcher & Regularly & Regularly & no & 1 \\
\hline 19 & Female & 20 & Student & Regularly & Regularly & no & 1.1 \\
\hline
\end{tabular}

Table 4. Antioxidant level in human blood of exposed groups compared to control groups of population $\left({ }^{\mathrm{a}} \mathrm{P}<0.001,{ }^{\mathrm{b}} \mathrm{P}<0.05\right)$.

\begin{tabular}{|c|c|c|c|c|c|c|}
\hline \multirow[b]{3}{*}{ Sex } & \multicolumn{3}{|c|}{ Addiction } & \multicolumn{3}{|c|}{ Without Addiction } \\
\hline & \multicolumn{3}{|c|}{ Antioxidant level (mM) } & \multicolumn{3}{|c|}{ Antioxidant level (mM) } \\
\hline & $\begin{array}{l}\text { Control } \\
(\mathrm{M}-\mathrm{n}=5 ; \\
\mathrm{F}-\mathrm{n}=0 ; \\
\text { C-n }=5)\end{array}$ & $\begin{array}{c}\text { Sewage } \\
(\mathrm{M}-\mathrm{n}=31 \\
\mathrm{F}-\mathrm{n}=6 ; \\
\mathrm{C}-\mathrm{n}=37)\end{array}$ & $\begin{array}{c}\text { Garage } \\
(\mathrm{M}-\mathrm{n}=17 \\
\mathrm{F}-\mathrm{n}=0 \\
\mathrm{C}-\mathrm{n}=17)\end{array}$ & $\begin{array}{c}\text { Control } \\
(\mathrm{M}-\mathrm{n}=7 ; \\
\mathrm{F}-\mathrm{n}=7 ; \\
\text { C-n }=14)\end{array}$ & $\begin{array}{l}\text { Sewage } \\
(\mathrm{n}=21)\end{array}$ & $\begin{array}{l}\text { Garage } \\
(\mathrm{n}=10)\end{array}$ \\
\hline Male $(\mathrm{M} \pm \mathrm{SD})$ & $0.77 \pm 0.04$ & $0.40 \pm 0.13^{\mathrm{a}}$ & $0.26 \pm 0.09^{\mathrm{a}}$ & $1.21 \pm 0.27$ & $0.46 \pm 0.14^{\mathrm{a}}$ & $0.39 \pm 0.06^{\mathrm{a}}$ \\
\hline Female $(\mathrm{M} \pm \mathrm{SD})$ & 0.00 & $0.39 \pm 0.07^{\mathrm{a}}$ & Nil & $1.20 \pm 0.14$ & $0.50 \pm 0.08^{a}$ & Nil \\
\hline Cumulative $(\mathrm{M} \pm \mathrm{SD})$ & $0.77 \pm 0.04$ & $0.35 \pm 0.11^{\mathrm{a}}$ & $0.26 \pm 0.09^{\mathrm{ab}}$ & $1.07 \pm 0.25$ & $0.49 \pm 0.10^{\mathrm{a}}$ & $0.39 \pm 0.06^{\mathrm{ab}}$ \\
\hline
\end{tabular}




\section{DISCUSSION}

The present study of that individual and/or combination of pollutant(s) brought significant decreases the level of antioxidant in both addicted and non addicted sewage and garage workers when compared to control group of population.

The adverse impacts of wastewater in sewage, washing water and air pollution from garage on occupationally exposed groups have already been studied nationally and internationally. Major research works have been conducted on the physical and chemical analysis of water and air pollutant by using various instruments. The health impacts with special reference to antioxidant level of human blood by occupationally exposed have been done internationally (Nadif et al., 1998; Penning et al., 1999; Gaetke and Chow, 2003; Riediker et al., 2004; Bergamini et al., 2009; Cuypers et al., 2010; Hertwin, 2013) but few works have been done in India (Tiwari, 2008) but many researchers have been documented on physico-chemical analysis of wastewater and air pollutants, no one has tried to establish biomarker study in relation to blood antioxidant level in blood of occupationally exposed groups of population at Kolkata, India.

Sewage water in municipality drain has already been reported to begenotoxic and it often to be mixed with small scale industrial effluent (Hough, 1997). Tiwari (2008) has already been documented that sewage water causes occupational health hazards in sewage and sanitary workers. Apart from organic pollutants sewage water contaminated by different metals especially lead $(\mathrm{Pb})$ and cadmium $(\mathrm{Cd})$. In urban area, large number of local automobile repairing shops has led to increased $\mathrm{Pb}$ contamination in sewage water (Hertwin, 2013). Air pollutants mainly hydrocarbons, aromatic hydrocarbons, particulate matters etc. are generated in the automobile repairing shop (garage).

The present results have close similarities with other research works ( $\mathrm{Li}$ et al., 2003; Ademuyiwa et al., 2005; Valco et al., 2006; Hertwin, 2013) in relation to oxidative stress that reduced antioxidant level in blood by occupational exposure when compared to control population (Table 1, 2, $3 \& 4$ ). The range of antioxidant level in human blood is 0.5 to 2.0 $\mathrm{mM}$. It was found significant changes $(\mathrm{P}<0.001$ or 0.05$)$ in addicted sewage and garage workers when compared with non-addicted groups.

All the exposed groups were showed significantly declining the antioxidant level when compared to control groups. It was observed in Table 4, the level of antioxidant in blood decreased significantly $(\mathrm{P}<0.001)$ in garage workers followed by sewage workers as occupational exposure along with addiction when compared with control groups. In nonaddicted groups of population there was the value of antioxidant level in blood also decreased significantly $(\mathrm{P}<0.001)$ in garage workers followed by sewage workers when compared with control groups.

The comparison between male, female and cumulative groups the values were not found statistically significant. When the comparison made between sewage and garage workers, the cumulative values were found to be statistically significant $(\mathrm{P}<0.05)$ for both addicted groups as well as non addicted groups. It is an evident from other research works that $\mathrm{Cd}$ and $\mathrm{Pb}$ in sewage water as well as hydrocarbons, aromatic hydrocarbons, particulate matters etc. in garage ambient air may have the damaging of free radicals and declining the antioxidant level in blood of human (Halliwell and Gutteridge, 2007; Cuypers et al., 2010). It was also noted that occupational exposure along with addiction (tobacco and alcohol) and food habit may have led more susceptible to oxidative stress, the results of the present study supported by observations of previous workers (Nadif et al., 1998 and Elena et al., 2013). 


\section{CONCLUSIONS}

In the present study it was concluded that the alarming effects on the antioxidant level in blood of occupationally exposed found significantly decreasing trends when compared to control groups of population (Penning et al., 1999; Hertwin, 2013), which may be the effects of individual and/or combination of water and air pollutants, though there no attempt has been made on physico-chemical properties of present water and air pollutants. This study is a preliminary assessment to know the potent biomarkers for oxidative stress and estimation of antioxidant level in blood due to occupational exposure. This study helps to know easy screening of biomarker assessment (Gupta et al., 2009) but further researches are needed in relation to biochemical, enzymological and genetic damage study. It was also observed the decreasing trends of antioxidant level in blood of exposed group along with addiction and food habit, which may have led to damage antioxidant defenses (Nadif et al., 1998; Cuypers et al., 2010).

\section{Acknowledgement}

The authors convey their gratitude to the Institute of Hematology and Transfusion Medicine, Medical College, for providing the necessary infrastructure for doing this study.

\section{References}

[1] Ademuyiwa O., R. N. Ugbaja, D. A. Ojo, A. O. Owoigbe, S. E. Adeokun, Environ. Toxicol. and Pharmacol. 20 (2005) 404-401.

[2] Bergamini C., Cicoira M, Rossi A, Vassanelli C. (2009) Eur J Heart Failure, 11:444-452.

[3] Brook R. D., Rajagopalan S., Pope A., Brook J. R., Bhatnagar A., Diez-Roux A. V., Holguin F., Hong Y., Luepker R. V., Mittleman M. A., Peters A., Siscovick D., Smith S. C., Whitsel L., Kaufman J. D., Circulation 121 (2010) 2331-2378.

[4] Cuypers A., M. Plusquin, T . Remans, et al., Biometals 23(5) (2010) 927-40.

[5] Elena I. Korotkova, Wolfhardt Freinbichler, Wolfgang Linert, Elena V. Dorozhko, Mariya V. Bukkel, Evgeniy V. Plotnikov and Olesya A. Voronova, Molecules. 18 (2013) 1811-1818.

[6] Gaetke L. M, Chow C. K., Toxicology 189 (2003) 147-163.

[7] Gupta R., Sharma M., Ramakrishnan L., Prabhakaran D., Reddy K. S., Journal of Biochemistry and Biophysics 46 (2009) 126-129.

[8] Halliwell B., Gutteridge J. M. C. (2007). In Free Radicals in Biology and Medicine. 4th edition. Edited by Halliwell B, Gutteridge JMC. New York: Oxford University Press; 187-267.

[9] Hertwin A., Met Ions Life Sci. 11 (2013) 491-507.

[10] Houh V. S., Mutat. Res. 277 (1992) 91-138.

[11] Li N., Sioutas C., Cho A., Schmitz D., Misra C., Sempf J., Wang M., Oberley T., Froines J., Nel A., Environ Health Perspect 111 (2003) 455-60. 
[12] Miller N. J., Rice-Evans C., Davis M. J., Biochem. Soc. Trans. 21 (1993) 95S.

[13] Miller N. J., Rice-Evans C., Free Rad. Res. 26 (1997) 195-199.

[14] Miller N., Rice-Evans C., Davis M. J., et al., Clin. Sci. 84 (1993) 407-412.

[15] Nadif R., Diallo L., Mayer L., Dusch M., Porcher J. M., Schneider P., Urschel M., Mur J. M., Auburtin G., Am J Ind Med. Sep 34(3) (1990) 272-279.

[16] Penning T., Burczynski M., Hung C., McCoull K., Palackal N., Tsuruda L., Chem Res Toxicol. 12 (1999) 1-18.

[17] Riediker M., Devlin R. B., Griggs T. R., Herbst M. C., Bromberg P. A., Williams R. W., Cascio W. E., Particle Fibre Toxicol. 1 (2004) 2.

[18] Tiwari Rajnarayan R., Indian J Occup Environ Med. 12(3) (2008) 112-115.

[19] Valkom M., Rhodes C. J., Moncol J., Izakovic M., Mazur M., Chem Biol Interact 160 (2006) 231-137.

[20] Vichit-Vadakan N., Vajanapoom N., Ostro B., Res Rep Health Eff Inst 154 (2010) 231-268. 